\title{
Anti-Māori themes in New Zealand journalism-toward alternative practice
}

\section{ABSTRACT}

Negative mass media representations of Māori are of major concern, impacting on Māori/Pakeha relations, how Māori see themselves, on collective health and wellbeing, and ultimately undermining the fundamentals of equity and justice in our society. In this article, we outline a number of important patterns that constitute the contextual discursive resources of such depictions identified in representative media samples and other sources and provide a set of alternative framings for each pattern. Our purpose is to challenge what Deuze (2004) has referred to as an 'occupational ideology' of journalism and ultimately to change Pakeha newsmaking practices that routinely undermine efforts to approach and attain social justice in the field of Māori/Pakeha relations in Aotearoa.

Keywords: Pakeha, journalism, representations, mass media, Māori, hegemonic discourse.

\section{ANGELA MOEWAKA BARNES, BELINDA BORELL, KEN TAIAPA, JENNY RANKINE, RAY NAIRN and TIM MCCREANOR Whariki Research Centre, Massey University}

I

N A highly mediated world (Fairclough, 1995; Hartley, 1982; Hodgetts \& Chamberlain, 2006), current media representations of Māori are of major concern as they: impact on Māori/Pakeha relations, affect how Māori see themselves and, indirectly, their collective health and wellbeing, and ultimately undermine the fundamentals of equity and justice in our society. From earliest contact Māori have been depicted negatively by European observers (Belich, 1996; Salmond, 1997; Ward, 1839) as uncivilised, savage, violent, ignorant and indolent (Belich, 1996; McCreanor, 1997; 
Salmond, 1991). Press accounts of Māori elaborated such descriptions (Abel, McCreanor \& Moewaka Barnes, 2011; Ballara, 1986; Colvin, 2010) in the changing circumstances of the early years of the settlement in service of the colonial project (Ballara, 1986; Thompson, 1954a, 1954b) and the legacy of this history is clearly evident in the contemporary mediascape (Abel, 1997; Hodgetts, Masters, \& Robertson, 2004; McCreanor, 1993; McGregor \& Comrie, 1995, 2002; Moewaka Barnes et al., 2005; Rankine \& McCreanor, 2004; Rankine, et al., 2011; Rankine et al., 2008).

Running through the vast flow of media accounts that have been studied, are clearly discernible; patterns and themes of anti-Māori discourse that have been described and analysed by multiple researchers (Abel, 1997; Matheson, 2007; McCreanor, 2008; Nairn \& McCreanor, 1991; Thompson, 1954a, 1954b). The research findings are invaluable, both as the context for interpretation and analysis of any body of media data and also as a potentially useful tool for community and professional members wanting to challenge and change the dismal status quo. We argue that the themes are effectively the generic discursive resources from which we build and elaborate the discourses and narratives that we use to explain and understand our everyday experiences (Wetherell \& Potter, 1992; Zelizer, 1993). The themes are also part of what Deuze (2004) has referred to as an 'occupational ideology' of journalism and are fundamental to the ways in which Pakeha newsmakers craft their work.

\section{Kaupapa Māori media theory and research}

Kaupapa Māori research and theory in the area of mass media journalism performance provides understandings centred in a Māori gaze. Its scope includes analysis of worldviews, identity and histories, and the issues of responsibility and accountability. More broadly, Kaupapa Māori media research and theory requires an examination of power relations and dominant hegemonic discourses and representations (Moewaka Barnes, 2011). Applications of this theory can inform scrutiny of a variety of media sites including television and in particular serve to positively progress media representations of indigenous and marginalised groups globally.

In this article we outline a number of the important patterns (see Table 1) identified in the representative media sample from our current study ${ }^{1}$ and other sources together with a set of alternative framings for each pattern. As Philo (2007) has pointed out in relation to understanding news: 'The key 
conclusion which we drew, in terms of methods, was that it was not possible to analyse individual texts in isolation from the study of the wider systems of ideologies which informed them.' (p. 183)

We argue that these materials represent an important resource to understand and change Pakeha interpretation and decoding of news items about Māori and Māori/Pakeha relations. Our goal is for this resource to be available for debate and discussion in communities, among researchers and media professionals, and, particularly, as a challenge to mass media outlets and a contribution to improving relations between Māori and Pakeha.

\section{Pakeha as norm}

The first pattern constructs Pakeha as the norm. Acknowledging the contested nature of the term Pakeha, we follow established practice of Māori commentators (Walker, 1990) and Pakeha change workers (Black, 2010; Huygens, 2008) using the term to mean settlers of European descent. This pattern is most important despite being primarily characterised by absence or silence about the ethnic identity of the most powerful individuals and groups in our society.

Although Pakeha are rarely named as a group they are routinely constructed as natural, the nation, the ordinary, the community, against which all other ethnic groupings are viewed and measured. As a result there is a dearth of overt reference to Pakeha in the media. Instead there are a series of cues that indicate who is being spoken of, particularly through the use of pronouns - us, we, our - to denote Pakeha, while Māori are marked with you, yours and the casual distancing to the third person plural — they, them, their.

[Also - Kiwis will remain free to walk the beaches around New Zealand's coastline, but the government is facing revolt from Māori over its plans for the foreshore and seabed. (The Press, 19 August 2003, cited in Phelan, 2006).]

Examples include the banner cover of Metro magazine from 2004 'Hone Harawira and the Māori party: what have we got to fear?' and the slogan for TV1 News 'One News, Our News', where the possessor's identity is implicit in the content of the bulletin (Comrie \& Fountaine, 2005; McGregor \& Comrie, 2002). Framings that distinguish Māori and other identified groups operate every time Māori are identified by ethnicity and Pakeha are not. The media rarely identify community leaders, violent offenders, politicians, clerics, child abusers, business people, fraudsters, sportspeople, academics, professionals or 


\begin{tabular}{|c|c|}
\hline Pattern & Effect \\
\hline Pakeha as norm & $\begin{array}{l}\text { Constructs Pakeha as the ordinary normal citizen and culture of New } \\
\text { Zealand }\end{array}$ \\
\hline One people & $\begin{array}{l}\text { New Zealanders are represented as a single culture in which all are } \\
\text { to be treated the same. }\end{array}$ \\
\hline Rights & Individual Pakeha right stake precedence over collective Māori rights \\
\hline Privilege & Māori are portrayed as having resources and access denied others. \\
\hline $\begin{array}{l}\text { Ignorance and } \\
\text { hypersensitivity }\end{array}$ & $\begin{array}{l}\text { Pakeha offend Māori because of ignorance, Māori responses are } \\
\text { unduly sensitive. }\end{array}$ \\
\hline $\begin{array}{l}\text { Good Māori } \\
\text { Bad Māori }\end{array}$ & $\begin{array}{l}\text { Māori are seen as good or bad depending on the argument of the } \\
\text { speaker; Pakeha are rarely described in this way. }\end{array}$ \\
\hline Stirrers & $\begin{array}{l}\text { Those who challenge the social order are depicted as troublemakers } \\
\text { who mislead others for their own ends. }\end{array}$ \\
\hline $\begin{array}{l}\text { Māori crime, } \\
\text { violence }\end{array}$ & Māori are seen as more likely to be criminal or violent than Pakeha \\
\hline Māori culture & $\begin{array}{l}\text { Māori culture is dipicted as primitive and inadequate for modern life, } \\
\text { and inferior to Pakeha culture. }\end{array}$ \\
\hline Māori inheritance & $\begin{array}{l}\text { Describes ancestry in fractions in a way that denies Māori concepts of } \\
\text { whakapapa and self-identification. }\end{array}$ \\
\hline Māori resources & $\begin{array}{l}\text { Critical of any return of significant resources to Māori as a denial of } \\
\text { Pakeha rights to exploit such opportunities. }\end{array}$ \\
\hline Māori success & $\begin{array}{l}\text { Small scale Māori projects that fit Pakeha business models and use } \\
\text { Māori culture can be viewed as positive. }\end{array}$ \\
\hline Treaty of Waitangi & $\begin{array}{l}\text { The Treaty is a historical document of little relevance to the contem- } \\
\text { porary setting; a barrier to development. }\end{array}$ \\
\hline
\end{tabular}

other newsmakers as Pakeha and yet our databases show that such identification is routine in relation to Māori (Rankine et al., 2011; Rankine et al., 2008).

Underpinning these constructions are a number of contradictory but extremely powerful assumptions about identity, audience and merit that are widely accepted and have been identified in analyses of disparaging coverage of Māori in news (Comrie \& Fountaine, 2005; Hodgetts et al., 2004; McGregor \& Comrie, 2002; Moewaka Barnes et al., 2005; Rankine et al., 2008). The assumptions include the one-sided assimilation or exclusion of Māori; the notion that the established order is just, efficient and right; that news making is neutral, fair and culture free; and that the target audience are a naturalised, unitary, egalitarian nation. 
Various complementary effects flow from this synergy of power and belief. First, there is the entrenchment of Pakeha culture as the obvious, unremarkable foundation of New Zealand society and nation. This is particularly important in rendering the ongoing colonising of land, resources, and identity a natural process. Second, because Pakeha norms are naturalised, the constant decontextualised comparison of Māori people, institutions, and practices with these norms appears to confirm Pakeha understandings of Māori weakness, dependence, and inferiority. Māori challenges to this invisibilising of dominance trigger defensive reactions among Pakeha about their power and control, and intensify opposition to identifying Pakeha as an ethnic/cultural group. This makes preference for masking labels such as 'New Zealander' more likely.

Alternative framings with the potential to change the tenor of the relationship between Māori and Pakeha are not difficult to construct. For example, we could celebrate Pakeha as one culture among many in Aotearoa/New Zealand so that Pakeha ethnicity is not seen as superior, normative, or universal. Pakeha culture could be shown as a regional variant of Western culture- - a combination of influences, elements and traditions. In news-reporting practice, the even-handed use of ethnic labelling would routinely 'flag' ethnic achievement, issues and challenges in ways that produced better understanding of all ethnicities and contributed to social cohesion and mutual respect.

\section{One people}

Given the 'Pakeha as norm' pattern, it is unsurprising that, when news needs to articulate Pakeha identity it does so using elements of the pattern we refer to as 'One People'. Cues to the use of the pattern are familiar phrases; the public, taxpayers, rate-payers, the community, New Zealanders, Kiwis, or the nation, meaning Pakeha. Māori are subsumed within such constructions unless they opt out. Another feature of this pattern is the intransigence about difference; asserting all members should have equal, as distinct from equitable, treatment, offering the clearly anti-Māori justification that we are all immigrants no matter what our waka. Also assumed are the ideas that cultural or ethnic differences are divisive, not real, or do not matter, that indigenous status and te Tiriti o Waitangi are irrelevant, and that majority rule is the fairest way to make decisions.

Examples of this pattern abound in editorials and unquestioning media approaches to sources who use these assumptions: 
The justification for the Māori seats is now gone. It is a move that will signify one country, one people. (Timaru Herald editorial, 7 February 2003)

Quite simply, whatever 'customary rights' might have once existed, the foreshore and the seabed must belong to all New Zealanders. (Otago Daily Times editorial, 2003)

[Or] Beaches for all (Otago Daily Times front page headline, 19 August 2003)

The use of the term 'New Zealanders' simultaneously excludes or subsumes Māori and disrupts the negotiated balance of 'democratic' voting power in favour of Pakeha.

This pattern legitimates treating everyone uniformly irrespective of circumstances, an essential resource for reporting news that must submerge intergenerational injustices and systemic harms arising from colonialism. At stake in such stories is the colonisers' illicit acquisition of the entire asset base of the sovereign Māori peoples, of which only a tiny proportion of the estimated net economic value has been grudgingly returned in response to sustained Māori efforts (Walker, 2002). This theme serves to devalue ethnic diversity, representing it as endlessly problematic or trivial and to undermine serious debate about New Zealand society, especially in relation to Te Tiriti. It justifies and enacts Pakeha control of most important decisions, resources, and institutions and the ongoing assimilation of Māori and other 'minority' interests.

Alternative framings are simple to pose but require Pakeha to honestly acknowledge the mana of tangata whenua as sovereign peoples, the damage done by colonisation, and the promises of Te Tiriti. Such changes would enable the understanding that unequal inputs are needed to attain equitable outcomes and allow progress on undoing the damage wrought to all of us by colonisation.

Rights and privilege

Closely related to the One People theme is a pair of reciprocal patterns that we call 'Rights' and 'Privilege'. Rights advances the notion that people are entitled to do what they want provided it does not infringe on the interests of others. It is cued by words such as democracy, equality, property, privacy, and phrases such as 'level playing field', and 'home as castle'. Aside from 
the fundamentally contentious nature of such constructions, this pattern is only loosely attached to the practical societal processes of laws, regulations, and their enforcement. Media examples include:

National has bowed to Māori Party wishes and agreed to support the highly contentious United Nations Declaration on the Rights of Indigenous Peoples (New Zealand Herald, 20 April 2010)

Foreshore showdown looms as fear of Māori rights escalates (National Business Review, 5 November 2010)

In both examples Māori rights are cast as threats to hegemonic individual rights, policed and settled through the Pakeha legal system, divorced from broader issues of societal power and justice. Given the primacy accorded these forms, the Rights pattern contributes to media disregard and scepticism around the guarantees of Te Tiriti o Waitangi and any claim based upon Maori or indigenous rights.

Alternatives include broadening the focus of western, rights-based arguments to include collective and indigenous rights, and conceptualising rights as fluid and negotiated rather than fixed, individualised, and legally defined. Adding the specifics of Treaty rights with genuine commitment to act upon them would mean that Māori aspirations were able to be reported in ways that are more accessible to Pakeha audiences and therefore improve support for just resolutions. It would also help Pakeha to understand that the Treaty is mostly about the settler presence in this country and that the provisions of Article 3 in the Treaty cover Pakeha needs.

\section{Privilege}

'Privilege' focuses on Māori, portraying them as having advantages or benefits that are unfair and racist because others are excluded. This representation is grounded in the belief that contemporary citizens should not be held accountable for past treatment of Māori no matter how unjust. The pattern is cued by phrases like special treatment, race-based, Treaty/grievance industry, 'the past is the past' and any system with allocations for Māori, including parliamentary seats, bureaucracy, sports teams, admission schemes, scholarships, fishing rights, and broadcasting arrangements. Media examples include:

'Spirituality or special treatment?' (New Zealand Herald headline,

12 October 2004) 
'Māori...will effectively be handed the equivalent sea space for 240 new marine farms - for nothing'. (The Independent, 25 August 2004).

National's [Emission Trading Scheme] to include special treatment for Māori” (TV3 News headline, 16 November 2005)

Key assumptions are the notion that 'equality' is undercut by any form of unearned advantage and that past excesses of colonisation have been fairly addressed. Media manifest the pattern in the intense but decontextualised scrutiny of any systemic or innovative efforts to address Māori concerns or claims for restitution. They are represented as unfair or racist, thereby masking social and institutional structures that consistently reinforce Pakeha privilege (Hodgetts et al., 2004). Treaty claims and settlements are treated as if they are fraudulent or even criminal (Abel et al., 2011, Nairn et al., 2009), thereby masking the fact that only minimal concessions are made in such arrangements.

Valuable advances could be secured by exploring the realities of entrenched Pakeha privilege (Borell et al., 2009) and more careful handling of the context within which any allocations for Māori are set. For instance, the legitimacy and efficacy of the Māori seats in parliament are constantly challenged by Pakeha, although the seats were originally established by the settler government to prevent the possibility that Māori would democratically dominate parliament.

\section{Ignorance and hypersensitivity}

Two further patterns, 'Ignorance' and 'Hypersensitivity', offer pseudo-psychological explanations for the sources of tension between Māori and Pakeha. Pakeha actions that offend Māori are portrayed as unintended or arising from lack of understanding, while Māori are depicted as over-reacting. It is implied that Māori are responsible for telling Pakeha about their culture and that, when transgressions occur, the fault lies with Māori. Key phrases in such explanations include political correctness, no sense of humour, touchy, take offence too easily, need to lighten up, build a bridge, get over it.

Protests about the length of sentences given to the Saxtons, convicted for stealing Ngai Tahu pounamu, provide an example. Supporters argued that they were out of line with similar, more serious offences. As spokesperson Lisa Zwarst said without challenge from the journalist or balance provided by 
another source: 'When all's said and done it's only some green rock' (Westport News, 3 April 2008, p. 2)

Asserting that pounamu is 'rock' implies that Ngai Tahu have both withheld the cultural foundations of their beliefs in its value and overreacted to the theft.

In the media when stories about breaches of Māori protocol or other offences, occur Māori are often made to look thin-skinned or secretive, obviating Pakeha responsibility for appropriate behaviour in Māori environments.

Overall, the effect is to blame Māori for Pakeha offences and to excuse persistent and deliberate Pakeha breaches of commonly understood Māori values and practices. These include mispronouncing te reo Māori, not bothering to learn the protocol of the marae or appropriate behaviours for other Māori situations such as tangi and powhiri. The media endorse those who wish to stop people speaking Māori or practising tikanga Māori in everyday situations, further undermining Māori cultural practices.

Acknowledgement that respect for Māori culture, language and practices is extremely important to identity in Aotearoa would be a major advance. Māori are unique to Aotearoa and contribute to national distinctiveness. New Zealand is one of the most monolingual countries in the world; learning Te Reo and developing cultural competence in tikanga Māori, enriches national life.

\section{Good Māori/Bad Māori}

Good Māori/Bad Māori is another key pattern that sees those who appear happy with their lot, 'fitting in' or achieving in colonial society described as 'good', while Māori who resist, seek restitution, demand recognition and change or do not achieve are 'bad'. The theme works most flexibly when the user does not specify who or how many are 'bad Māori'; those who resist or protest can then be dismissed as a minority, estranged from their people.

Terms that cue the use of good Māori include: law-abiding, polite, happy, rural, older, hard-working, dignified, co-operative, punctual, clean and tidy, footing it with the rest of us. Bad Māori include: poor, sick, lazy, urban, young, criminal, aggressive, complaining/protesting, bludgers, stupid/dumb, greedy, dishonest.

These divisions appear in the media as both specific and generalised divide-and-rule tactics. Note the flexibility in these representations of Hone Harawira: 
No longer is Harawira the fire-wielding, foul-mouthed attack-dog, but the considered, studious critic seeking cross-party support (Otago Daily Times Online News, 31 July 2010)

Hone Harawira's performance is contrasted with earlier behaviour that saw him classified as a menace. As situations change, again he is criticised further using this theme by comparing him with another Māori who is apparently behaving well.

It's time to knuckle down, Hone. Go look at your colleague, Te Ururoa Flavell, as an example of someone who does the hard yards and is mightily respected for it. (John Armstrong, column, New Zealand Herald, 23 October 2010)

It is rare for such contrasts to be made in such a way that Māori appear better than Pakeha; almost every negative statistic from violence to socio-economic status is presented as an implicit comparison with Pakeha that makes Māori look bad.

Clearly such practices rest upon the idea that Pakeha have the ability and right to judge Māori, but not the other way around. This notion is also founded on deeper assumptions about the inferiority of all cultures but Pakeha. In this sense all Māori are bad although some are less trouble than others, but the existence of the latter means that the former are deliberately making things difficult for themselves through lack of judgement and poor life choices.

In the media these processes of judgement, as well as any discussion of the rationale for them, are silent or muted so that they are taken as normal and natural. Both overtly and more subtly, Māori are blamed for their own situations, disparities and difficulties.

More constructive understandings would include the recognition that Māori are diverse, like any group, with a range of opinions, and that Pakeha judgements of 'Good' and 'Bad' are fickle and defined by their own interests. It would be useful to either cease the divide-and-rule approach or adopt it in an even-handed fashion so that Pakeha are similarly represented. News-makers in particular need to work out conscious protocols to cover how identifying people as being Māori is relevant to the telling of any particular story.

The 'Stirrers' theme is a refinement of the 'Bad Māori' theme and focuses on those who actively resist colonial power. As Abel (1997) has pointed out, 
this theme is manifest in differential use of terms such as terrorist, extremist, activist, radical and protester, in an effort to isolate such leaders from their iwi and community networks. For example, Phelan (2009) found that journalists overwhelmingly applied the labels 'radical' and 'activist' to Māori during the Foreshore and Seabed debate in 2003/4, and only once to the government's legal intervention. Those who challenge the status quo are portrayed as 'stirrers' who mislead others and cause tension for their own political ends. The cues are the terms above as well as phrases such as 'bleeding heart liberals' and 'fellow traveller'. Examples abound from coverage of many confrontations that Māori are forced into in enacting tino rangatiratanga:

Māori activists occupied the school's buildings on Tuesday, saying the government had no right to sell the school because it was on confiscated Māori land. (Taranaki Daily News, 8 March 2007)

Helen Clark's dismissal of the Foreshore and Seabed Hikoi-presented without any balancing source or any challenge from the journalist involved-is a particularly virulent example, both naming her opponents and branding them bad:

The Ken Mairs, the Harawira family, the Annette Sykes - the haters and wreckers. (Prime Minister Helen Clark, One News, 3 May 2004)

Key assumptions at work here are that such people are a tiny minority who upset otherwise harmonious relations. Critically, media portray the views expressed by such people as not widely shared by Māori people, and these actors as simply using the issues they raise as vehicles for their own power agendas.

These framings in the media distract attention from the substance of grievances by focusing on the supposed aggression or irrationality of proponents of Māori rights. Another effect masks the wider support from within Māoridom for those who are at the frontlines of particular struggles.

Genuine alternative approaches here are needed to acknowledge and support Māori leaders and innovators who take public stands against ongoing colonial practices. There is also a need to critique discourses that seek to marginalise Māori tino rangatiratanga and Treaty-based processes. 


\section{Māori crime and violence}

Closely linked to the Bad Māori pattern are a series of ideas that constitute the theme of Māori Crime. Built upon Western cultural stereotypes of the 'Other' (McCreanor, 1997; Salmond, 1991), the pattern centres on the notion that Māori are inherently violent and criminal (McCreanor et al., 2011). Terms including primitive, tribal, savage and uncivilised, underpin contemporary usages in which 'gang', 'domestic violence, home invasion, terrorism and similar ideas are a default setting for Māori. Other elements include theft, corruption, nepotism, fraud and general dishonesty. The following example implies that wrongdoing was involved in this case despite the fact that charges were never laid.

Companies owned by the daughter of Te Wananga o Aotearoa head Rongo Wetere earned more than $\$ 74.2$ million in five years from contracts with the institution. (New Zealand Herald, 3 December 2005)

Key assumptions are that Māori and Māori men in particular, are inherently violent and criminal, and that these characteristics are cultural or even genetic. Also part of the themes are the ideas that Māori accept and cover up violence and that they are generally unconcerned about using crime to support themselves. In the media the pattern links to media frames around deviance and marks Māori as the 'undifferentiated Other' in ways that create fear and alienation in the intended audience. Our recent study shows that crime is the second highest category of Māori stories in a representative sample gathered from newspapers (Rankine et al., 2011). Particular Māori families in which offences have occurred are stigmatised in ways that weaken efforts to remedy contexts that have often arisen from histories of tragedy and trauma. Another major effect is to render Pakeha crime and violence, which are not ethnically marked, invisible, masking the relativities and diverting attention from the systematic impacts of repression and marginalisation of Māori by both state and society in general.

Alternatives need to take a consistent approach that routinely identifies ethnicity in all stories about offenders sought by police in ways that more fully contextualise the relativities of Māori and non-Māori crime. Also needed is a better understanding of the impacts of family (poverty, dislocation, beaten for speaking Māori at school) and colonial histories (Land Wars, raupatu, racist policies) within which events occur, not excuse or mitigate offensive 
behaviour, but to put it in the broadest context in which remediation can hope to bring positive change. Change is needed in the media culture on the values that support the current sensationalist crime reporting styles to approaches that support equitable preventative measures and remediation.

\section{Māori culture}

The theme 'Māori Culture' asserts that all aspects of Māori culture, including language, are primitive, irrelevant and inadequate in the modern context. Philosophically, intellectually, socially and practically, Māori knowledge and practice is seen as inferior, inequitable and untenable, and the Māori world is seen as dependent upon the knowledge and resources of the colonial society. On the other hand, Pakeha will often appropriate non-threatening aspects of Māori culture to mark their own identity as New Zealanders.

This pattern is articulated in a language of superiority and contempt that implicitly constructs selected or putative aspects of the Māori world as not measuring up to its Pakeha equivalents. Tropes such as 'Māori time' (always late), Māori house (unpainted ruin), 'Māori land' (ragwort and blackberry), 'Māori car' (wreck), Māori way (time-wasting) and similar, signal this stance.

Some Māori ceremonies in schools are time-wasting and sexist, says Education Minister Trevor Mallard. (New Zealand Herald, 25 September 2004)

The reporters failed to question Mallard's assumption that Māori traditions undermine equality for girls, while Pakeha traditions support it and headlines supported his construction.

Another story in the media frequently portrayed Māori as unreasonably holding up roading progress because of spiritual and cultural beliefs.

Ngati Naho kaumatua Sonny Wara said Karu Tahi, who lived in a swamp, was the taniwha the hapu was most concerned about, but there were two other taniwha, Waiwai and Te Iaroa, which could be disturbed by the roadworks. (New Zealand Herald, 8 November 2002)

The key assumption in this domain is that there is a hierarchy of cultures from tribal/primitive at the bottom to sophisticated, global/capitalist at the top. Alongside this idea is a misrecognition of Māori culture as being frozen at the point of first contact with later development and revisions being 
inauthentic. In the media these elements combine to construct Māori culture as marginal or ceremonial and justify the ongoing dominance of the colonial socio-political form. These framings also encourage Māori to believe their culture is inferior and support assimilation of Māori.

Alternative discourse in this arena sees Māori culture as adaptive, developing and not to be explained by its difference to Pakeha culture. It acknowledges that Māori cultural concepts such as rangatiratanga, manawhenua, kaitiakitanga, powhiri and tangihanga are legitimate, complex and positively influential on Pakeha culture. It is understood that all cultures are diverse and fluid and have their own measures of what is valuable. Pakeha engagement with Māori culture is a privilege; Māori engagement with Māori culture is a right.

\section{Inheritance}

Sitting alongside the marginalisation and assimilation of Māori culture is the theme of 'Inheritance' that questions the very basis of Māori existence by calling genetic integrity into question. Intermarriage supposedly means that there are few 'real Māori' left; Māori are no longer a distinct people and shouldn't be able to claim any special treatment of benefits.

Talk of blood-fractions, especially 'full-blooded' or 'pure' blood, 'halfcaste' or part-Māori all signal reference to this theme. Phrases such as 'drop of Māori blood', 'Māori fingernail', born-again Māori, waka blonde, plastic Māori and the like express it in diverse settings.

Such positions are clearly based on assumptions about genetic or biological determination of Māori identity in which racial purity and cultural authenticity elide. Claiming a Māori identity is aligned with acquiring certain privileges, rather than representing identity as both a valid political and personal position. Further it is assumed that Māori and Pakeha are mutually exclusive categories; mixed ancestry dilutes Māori identity but apparently not Pakeha identity. As the outlier, Māori identity must be evidenced and proven, whereas this is not a requirement for Pakeha

In the media this pattern works to reinforce certain cultural markers as valid indicators of Māori identity. This reinforces the inevitability of Māori assimilation and requires Māori to define and justify their identity constantly. Effects include the apparent reduction in size of the Māori population and the undermining of legitimate claims by tangata whenua. Alternatively, Māori (but never Pakeha) are identified, especially in accidents, crime and misdemeanours, by police, ambulance officers and the like, on the basis of 
physical characteristics including skin colour, hair, facial features, style of speech (McCreanor et al., 2011).

He is described as Māori, over 1.8m tall, medium build, and was last seen wearing a dark hoodie and dark trousers. (Gisborne Herald, 4 December 2007)

One of the important counter-measures that can be taken in this domain is to discard the retrograde discourses of race and clarify the meaning and importance of culture and ethnicity to identity development and maintenance. It is also important to recognise the validity of self-identification and acknowledge that whakapapa expresses an integrated relationship between Māori ancestry, ethnicity, culture and identity.

\section{Māori resources}

This theme focuses on the notion that potential or actual Māori control of significant resources-for example, land, fisheries, forestry, water or money_is a threat to non-Māori.

Talk of special rights, fisheries quota, electromagnetic spectrum allocations, customary fisheries, Crown Rental Forestry Trust, Treelord deal, Māori land 'gifted' back, compensation, indigenous rights, underpin common phrases such as 'Pakeha are missing out', 'give Māori an inch and they'll take a mile'. Tribe: Pay us for air rights (New Zealand Herald, 7 October 2004)

The key assumption here is that assets including fish, forests, minerals, water, petrochemicals, geothermal energy, biodiversity and the like are the property of the Crown. There also appears to be an assumption that ownership of such resources by Māori represents an unreasonable 'lock-up' of potential economic gain, whereas individual Pakeha ownership or collective ownership by all 'New Zealanders' is not a threat. This kind of framing masks the reality of Pakeha control of wealth in Aotearoa by focussing attention on Māori-controlled resources and ignoring the fact that for example 95 percent of the land (Ministry of Justice, 2011) and over 80 percent of the fish quota (Te Ara, 2009) are in non-Māori hands.

Alternative accounts in this area would acknowledge that Māori concepts of resource management are legitimate and sustaining; for example in the way 
that wairua and kaitiakitanga promote conservation and sustainable development. Māori control of resources is more likely to be managed with a long term view with clear principles and values already in place. It is also the case that Treaty settlements and the return of resources to their original guardians are a significant and positive achievement that everyone can be proud of, enhancing social cohesion and stability.

\section{Māori success}

The last theme that we discuss is that of Mãori Success which pays some acknowledgement, although frequently grudging, to selected Māori innovations and outcomes. Particular forms of Māori economic development in the arts, business and education are celebrated, especially those using Pakeha business structures and aspects of Māori culture for branding. Clearly this theme relates to others such as Good Māori and Financial Management as well as Privilege (since success is frequently attributed to affirmative action) but it is encountered often enough in the media to warrant its inclusion separately.

Cues to the use of this theme are not so well-worn as some of the earlier examples but there is an emphasis upon youth, innovation and success.

A new 'cybertribe' of Māori artists is harnessing the web to take paintings, sculpture, mixed media, weaving and glassworks to the world art market. (New Zealand Herald, Business page 12, 10 September 204)

Seven marae in the Feilding and Halcombe area are banding together to jointly develop their resources and open future business opportunities. Manawatu Standard, 7 February 2007 p. 4)

Underpinning this pattern are assumptions that success while rare, can occur and be defined in Pakeha terms. When aligned to Pakeha agendas and values Māori success can be seen as positive so long as it does not threaten Pakeha wealth or power.

Like the Good Māori/Bad Māori pattern, this theme identifies winners and implies losers. Often the former are people of extreme talent, and indeed they have to be to get a mention in the media. Highlighting such success reinforces the idea that everyone has equal opportunities.

More helpful framings would include the notion that Māori are often successful in spite of stereotypes and racism. Dominant notions of 'success' 
also need to be examined as success can occur in a variety of ways. Attention also needs to be given to Māori values and aspirations in their innovations and enterprises, where self-promotion is generally discouraged.

\section{Te Tiriti o Waitangi}

This pattern is entwined with much of what we have already articulated; Te Tiriti is depicted as a historical document, more divisive than inspirational, blocking development but otherwise having little relevance to the contemporary setting. Phrases such as 'Treaty industry', 'grievance mode', 'gravy train' along with calls to dispense with it cue the use of this pattern.

Treaty of Waitangi claims are continuing to delay the sale of Masterton's abandoned schools. (Dominion Post, 19 February 2008)

...when the orchestrated grievance display that is Waitangi Day passes... (Manawatu Standard editorial, 7 February 2007)

The central assumption here is that Pakeha are entitled to unilaterally determine the worth and meaning of the Treaty. In media use this undermines any recourse to the Treaty in debates or conflicts between Māori and Pakeha, giving preference to the established Pakeha institutions of police, courts and Parliament to settle issues.

Alternatives include the understanding that the Treaty is a contract by which Pakeha can live legitimately and justly in Aotearoa; according Māori rights as tangata whenua. The Treaty needs to be acknowledged as an agreement between two sovereign peoples, with Māori having an equal say in any interpretation. Work is needed to enshrine it as the foundation and guide of a new constitution that enables the achievement of a just, Treaty-based future.

\section{Conclusions}

These then are some of the key elements of the standard story along with some attempt to challenge them with alternative resources. The list is not exhaustive but covers many of the key ideas that permeate Pakeha talk and media discourse about Māori and the Māori world. Because the alternatives are themselves marginal discursive forms, they are not 'easy to hear', not comfortably colloquial and likely to attract rebuttal and rejection. These features are even more evident when narratives based on each set of resources are set against each other. 
Here is how a standard story version might sound:

This country needs to get over this politically correct rubbish about colonisation. We used to have the best race relations in the world before a few radicals started stirring up trouble with Māori, filling their heads with ideas and hopes that are completely unrealistic. All this nonsense about the Treaty which is ancient history that I wasn't party to, has got even good Māori, riled up, demanding and troublesome, thinking that they should get land and compensation. The problem is that Māori culture can't foot it in the modern world and it's being swept aside the same way the Māori did to the Moriori-at least we didn't eat them. Māori are pretty upset about this but they've started ramming their language and their powhiris and their tangis down our throats. They need to move on and forget about losing what they never owned, and put their shoulder to the common wheel for the national good. We're one people now, Kiwis, and we don't want Māori rights for this and that, privileging them and dividing our country.

A narrative based on the alternative resources might sound like this:

We can decolonise Aotearoa to create social equity among the peoples of this nation. We need to acknowledge and enact the Treaty and the indigenous rights of tangata whenua to redress the wrongs and as guides to the ways forward. Fairly resourced, Māori culture as the vehicle for Māori values, beliefs and aspirations will support its people as our society adapts to an ever-changing global world. Māori leaders need to be recognised as change agents, innovators and visionaries for a just society. Māori people as community, iwi and nation are inspiring, leading and supporting the development of sustainable futures for all peoples of Aotearoa. Pakeha in particular can educate themselves to understand, endorse and cooperate in the development of Māori aspirations and self-determination, to create a national identity based on the diverse strengths of all groups that make up our society.

Our challenge to media producers, and to Pakeha media audiences, is to find the ways in which you can tell and read the news differently to represent Māori more fairly and our social order more honestly. To deal with this challenge, news professionals need to know a great deal more about the sources of our power and the resources that underpin our hegemonic discourses. So equipped they can approach Māori stories in ways that will produce the decolonising outcomes desirable for all. Our hope is that taken up, breathed into life, infused with your energy, applied and practised in your settings, 
that these raw resources can be part of the work required to build a just and equitable nation.

\section{Note}

1. The project Media, health and wellbeing in Aotearoa was funded by the Health Research Council of New Zealand.

\section{References}

Abel, S. (1997). Shaping the news : Waitangi day on television. Auckland: Auckland University Press.

Abel, S., McCreanor, T., and Moewaka Barnes, A. (2011). Reporting te tiriti: Producing and performing the colonial society. In M. Hirst, V. Rupar and S. Phelan (Eds.), The Politics and Power of New Zealand Journalism (pp. 65-79). Auckland: AUT Media.

Ballara, A. (1986). Proud to be white: A survey of racial prejudice in New Zealand. Auckland: Heinemann.

Belich, J. (1996). Making peoples: A history of the New Zealanders from Polynesian settlement to the end of the nineteenth century. Auckland: Penguin.

Black, R. (2010). Marking the unmarked: Pakeha cultural markers in dominant group members talk in Aotearoa. Unpublished $\mathrm{PhD}$ thesis, University of Waikato, Hamilton.

Borell, B., Gregory, A., McCreanor, T., Jensen, V., and Moewaka Barnes, H. (2009). It's hard at the top but it's a whole lot easier than being at the bottom: The role of privilege in understanding disparities in Aotearoa/New Zealand. Race/Ethnicity, 3(1), pp. 29-50.

Colvin, G. (2010). The soliloquy of whiteness: Colonial discourse and New Zealand's settler press 1839-1873. A thesis submitted in partial fulfilment of the requirements for the degree of Doctor of Philosophy in Journalism, University of Canterbury.

Comrie, M., and Fountaine, S. (2005). On-screen politics: the TVNZ charter and coverage of political news. Political Science, 57(2), pp. 29-42.

Deuze, M. (2004). What is journalism? Professional identity and ideology of journalists reconsidered. Journalism, 6(4), pp. 442-464.

Fairclough, N. (1995). Media discourse. London: Arnold.

Hartley, J. (1982). Understanding news. London: Methuen.

Hodgetts, D., and Chamberlain, K. (2006). Developing a critical media research agenda for health psychology. Journal of Health Psychology, 11(2), pp. 317-327.

Hodgetts, D., Masters, B., and Robertson, N. (2004). Media coverage of 'decades of disparity' in ethnic mortality in Aotearoa. Journal of Community and Applied Social Psychology, 14, pp. 455-472.

Huygens, I. (2008). Processes of Pakeha change in response to the treaty of Waitangi. $\mathrm{PhD}$ thesis, University of Waikato, Hamilton.

Matheson, D. (2007). The interpretative resources of Aotearoa New Zealand journalists reporting on Māori. NZJMS, 10(2), pp. 91-105. 
McCreanor, T. (1993). Mimiwhangata: Media reliance on Pakeha commonsense in interpretations of Maori actions. Sites, 26, pp. 79-90.

McCreanor, T. (1997). When racism stepped ashore: Antecedents of anti-Māori discourse in New Zealand. New Zealand Journal of Psychology, 26, pp. 43-57.

McCreanor, T. (2008). Discourse, media and health in Aotearoa. In K. Dew \& A. Matheson (Eds.), Understanding health inequalities in Aotearoa/New Zealand (pp. 85-96). Dunedin: University of Otago Press.

McCreanor, T., Rankine, J., Moewaka Barnes, A., Borell, B., Nairn, R., and McManus, A.-L. (2011). The association of crime stories and Māori in Aotearoa New Zealand print media. Howard Journal of Communications, submitted 7 April.

McGregor, J., and Comrie, M. (1995). Balance and fairness in broadcasting news 1985-1994. Palmerston North: Massey University.

McGregor, J., and Comrie, M. (Eds.). (2002). What's news? Reclaiming journalism in New Zealand. Palmerston North: Dunmore Press.

Ministry of Justice. (2011). The Māori Land Court. Retrieved on 18 May 2011, from www.justice.govt.nz/courts/maori-land-court

Moewaka Barnes, A. (2011). Nga kai para i te kahikatoa: Māori pioneers of filmmaking. Unpublished $\mathrm{PhD}$ thesis, University of Auckland, Auckland.

Moewaka Barnes, A., Gregory, M., McCreanor, T., Nairn, R., Pega, F., \& Rankine, J. (2005). Media and te tiriti o Waitangi 2004. Auckland: Kupu Taea.

Nairn, R., \& McCreanor, T. (1991). Race talk and common sense: Patterns in Pakeha discourse on Māori/Pakeha relations in New Zealand. Journal of Language and Social Psychology, 10(4), pp. 245-262.

Nairn, R., McCreanor, T., Rankine, J., Moewaka Barnes, A., Pega, F., and Gregory, A. (2009). Media surveillance of the natives: A New Zealand case study-Lake Taupo air space. Pacific Journalism Review, 15(1), pp. 131-148.

Phelan, S. (2006). The mediatised antagonism of the New Zealand/Aotearoa 'foreshore and seabed' conflict [Online proceedings of the British Political Studies Association 2006 Conference, Liberty, Security and the Challenge of Government, Reading 4-6 April]. Retrieved on 10 October 2007, from www.psa.ac.uk/2006/pps/Phelan.pdf

Phelan, S. (2009). The newspaper as political antagonist: Editorial discourse and the othering of Māori perspectives on the foreshore and seabed conflict. Journalism, 10(2), pp. 217-237.

Philo, G. (2007). Can discourse analysis successfully explain the content of media and journalistic practice? Journalism Studies, 8(2), pp. 75-196.

Rankine, J., and McCreanor, T. (2004). Colonial coverage: Media reporting of a bicultural health research partnership. Journalism, 5(1), pp. 5-29.

Rankine, J., Nairn, R., Abel, S., McManus, A.-L., McCreanor, T., Moewaka Barnes, A., Gregory, A. (2011). Content and source analysis of newspaper items about Māori issues. Journalism: Theory, Practice and Criticism, under review.

Rankine, J., Nairn, R., Moewaka Barnes, A., Gregory, M., Kaiwai, H., Borell, B., \& McCreanor, T. (2008). Media \& te tiriti Waitangi 2007. Tamaki Makaurau/ Auckland: Kupu Taea: Media and Te Tiriti Project. 
Salmond, A. (1991). Two worlds: First meetings between Māori and Europeans 1642-1772. Auckland: Viking.

Salmond, A. (1997). Between worlds : early exchanges between Māori and Europeans, 1773-1815. Auckland: Viking.

Te Ara. (2009). Fishing industry: who owns the quota? Retrieved on 7 June 2011, from www.teara.govt.nz/en/fishing-industry/7

Thompson, R. (1954a). Māori affairs and the New Zealand press, Part II. Journal of the Polynesian Society, 63(1), pp. 1-16.

Thompson, R. (1954b). Māori affairs and the New Zealand press, Part III. Journal of the Polynesian Society, 63(3-4), pp. 216-227.

Walker, R. (1990). The role of the press in defining Pakeha perceptions of the Māori. In P. Spoonley and W. Hirsh (Eds.), Between the lines: Racism and the New Zealand media (pp. 37-46). Auckland: Heinemann Reed.

Walker, R. (2002). Māori news is bad news. In J. McGregor and M. Comrie (Eds.), What's News: Reclaiming journalism in New Zealand. Palmerston North: Dunmore.

Ward, J. (1839). Information relative to New Zealand. London: J.W. Parker.

Wetherell, M., and Potter, J. (1992). Mapping the language of racism: Discourse and the legitimation of exploitation. New York: Harvester Wheatsheaf.

Zelizer, B. (1993). Has communication explained journalism? Journal of Communication, 43(4), pp. 80-88.

All the researchers who have contributed to this article are from the Whariki Research Group, SHORE and Whariki Research Centre, School of Public Health, Massey University, Auckland:

Angela Moewaka Barnes is a Māori media researcher with special interests in studies of film and mass media representations of indigenous people.

Belinda Borell is a Māori social scientist with research interests in power, privilege and whiteness as domains within the study of the health and wellbeing of indigenous people.

Ken Taiapa is a Māori researcher with an interest in audience interpretation and meaning-making around news stories.

Jenny Rankine is a Pakeha researcher with particular interest in media representations in the fields of gender, ethnicity and culture.

Ray Nairn is a Pakeha research psychologist with a track record in the study of media representations and social justice. 
Tim McCreanor is a Pakeha social scientist with a special interest in qualitative research and discursive methods in the study of culture, equity and justice. t.n.mccreanor@massey.ac.nz

\section{PACIFIC MEDIA CENTRE}

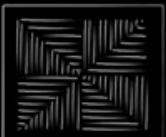

PAEIFIE $M E \in I A$ EFNTRE TE AMOKURA

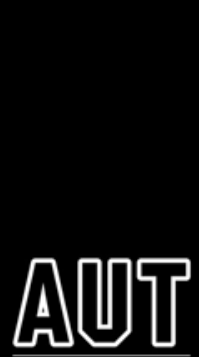

UNIVERSITY
The Pacific Media Centre (Te Amokura) is the only media research and community resource centre of its kind in Aotearoa/New Zealand and has a strategic focus on Māori, Pasifika and diversity media and community development:It was established by AUT University's Faculty of Design and Creative Technologies in 2007. having evolved from a cluster of research and community collaborations within the School of Communication Studies.

PMC activities include:

- International book and research publication

- Publication of the peer-reviewed Pacificjournalism Reviewresearch journal

- Publication of Pacific Media Centre Online as a mediaresource and postgraduate outlet

- Publication of Pacific Media Watch, a regional media monitoring service

- Journalism and media research opportunities

- Asia-Pacific internships for postgraduate students

www.pmc.aut.ac.nz | pmc国aut.ac.nz 